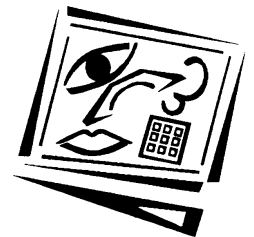

\title{
Primary school teachers' use of digital resources with interactive whiteboards: The Australian context
}

\author{
Damian Maher \\ University of Technology, Sydney \\ Renata Phelps and Nikkita Urane \\ Southern Cross University
}

Mal Lee

Education Consultant

\begin{abstract}
As interactive whiteboards appear in increasing numbers in primary classrooms, questions will continue to be asked about the effectiveness of these devices in supporting teaching and learning. It is not the board itself, however, which is likely to make a difference to student learning outcomes, but the resources which teachers choose to use in conjunction with their board. This study investigated what digital resources Australian primary school teachers are using when teaching with interactive whiteboards and the factors affecting their choice of such resources. Data were collected from 116 teachers from 13 primary schools in regional and metropolitan areas via an online survey and follow-up focus groups. While flipchart software plays an important role in delivery of lessons, a broad range of resources, particularly online, interactive and multimedia resources are utilised. National, pedagogical and curriculum relevance are critical influences on Australian teachers' resource choice and word-of-mouth plays a dominant role in influencing patterns of use. There are important implications from the study for teachers, school leaders, teacher educators and producers of digital resources.
\end{abstract}

\section{Introduction}

Interactive whiteboards (IWBs) have, over a relatively short period of time, assumed a prominent role in many classrooms in developed (and some developing) countries. Between 2005-2010 global IWB sales rose from 257,261 to 1,029,280 and are projected to rise to 1,336,000 by 2012 (Lee, 2010). The number of countries purchasing over 10,000 boards a year grew from three in 2005 to nine in 2009 (Futuresource Consulting, 2010a; 2010b). Adoption of IWBs has been fastest in the UK where National funding of around $£ 50$ million (Hall \& Higgins, 2005) saw IWBs installed in over $75 \%$ of classrooms (Lee, 2010; Futuresource, 2010). Denmark and the Netherlands are said to have IWBs installed in 40-42\% of their classrooms whilst the USA, Mexico and Ireland have just fewer than 30\% (Lee, 2010). At the end of 2009, 31\% of Australian classrooms were equipped with IWBs (Futuresource, 2010a; 2010b; Lee, 2010).

It is not, however, just the physical IWB that influences the teaching and learning experiences occurring in classrooms. Rather it is the resources that teachers choose to 
use on their board that will have the most significant impact on educational outcomes. To date, limited research has examined the choices that teachers make regarding the digital resources they use with IWBs.

It is within this context that this study was conducted. The research aimed to investigate what digital resources Australian primary school teachers are using when teaching with interactive whiteboards and the factors affecting their choice of such resources.

This paper will first provide some background regarding the relationship between IWB hardware and software, and an overview of related literature. The research context and methods are then described and both qualitative and quantitative data discussed. The paper concludes with findings and implications for teachers, school leaders, teacher educators and, importantly, for wider industry, particularly producers of digital content.

\section{The relationship between IWB hardware and software}

IWBs are essentially a large whiteboard-like surface which acts as an 'input' device to a computer. When combined with a data projector to display the computer monitor's image onto the surface of the board, they function as a 'touch-sensitive screen'. IWBs retain many of the features of a traditional teaching board (i.e. chalkboard, blackboard or whiteboard) including the ability to visually display writing or drawing to a room of students. In addition, however, they add the many capabilities of computer technology such as saving, editing, Internet access and multimedia (Lee \& Winzenried, 2009). IWBs are commonly used to show instructional videos, web-based resources and presentations and to create digital flipcharts and manipulate text for text construction and handwriting (Hall \& Higgins, 2005).

IWBs are usually supplied with software that is installed on the computer attached to the board. Designed particularly for teachers, this software typically acts like presentation software, but includes such functions as handwriting recognition, drawing capabilities, audio recording and playback, hyperlinking and file embedding functions, screen capture (still and video) tools, and extensive multimedia galleries. Examples of built-in resources include Flash-based interactive rolling dice, timers, grid paper and audio files that might be used to signify correct or incorrect responses (e.g. cheers or hands clapping). Each of the major IWB companies produce and distribute their own proprietary version of this software (examples include SMART Notes, ActivInspire and Easiteach). While recognising that each brand has its own variations on names, we henceforth refer to this software as 'flipchart' software.

IWB hardware and software has, of course, been developed by private industry and the battle for 'market share' has been cut throat. The key companies have powerful marketing capacity, and the financial backing necessary to offset the often high initial expenses until the products reach common acceptance. As with other technologies, private industry has the potential to influence patterns of use of IWBs as well as the resources promoted for use on them (Lee \& Winzenried, 2009).

Flipchart software, for instance, has become integrally associated with the IWB itself and there is potential for uncritical or unaware teachers or school leaders to confuse the capability of the software with the functionality of the hardware, or to perceive 
flipchart software as the dominant domain of the IWB. However, flipchart software can be run on any computer (with or without an IWB) and virtually any software that runs from the attached computer can be interacted with via the IWB. A number of companies have actively marketed their software emphasising that they are 'IWB compatible', implying that other software or resources may not be. Sometimes it is not until IWBs are well embedded in a school context that this may become apparent.

For the purposes of this paper we use the term "digital resources" to refer to the wealth of hardware and software that can be used in conjunction with an IWB. This might include anything from DVD players, tablets or personal response (voting) systems to software such as a numeracy 'game', a website or content management platform or a Flash-based 'learning object' [defined by Kay \& Knaack (2005) as an interactive web-based tool that supports the learning of specific concepts by enhancing, amplifying, and/or guiding the cognitive processes of learners]. Together with more traditional computer applications such as office suites (word processors, spreadsheets, databases etc.), or video or graphic editing applications, these resources can all be valuable tools to support learning and teaching.

\section{Make it and they will come?}

The large-scale investment in IWBs in the 2000s, particularly in the UK, stimulated a growth in the production of interactive teaching materials, both from private industry and from government (Lee \& Winzenried, 2010). Globally there has arisen a plethora of commercial houses and education authorities producing a wide range of digital resources for teachers.

Many producers of digital content, and education authorities in particular, appear to work on the assumption that if they produce digital resources, teachers will flock to use them. In the UK, for example, despite an immense national investment in instructional technology and teacher learning, the 2009 Becta Review (Becta, 2009) revealed that only $10 \%$ of teachers were using the provided virtual learning environment (VLE). Similarly, Kitchen, MacKenzie, Butts and Finch (2006) showed that only $22 \%$ of UK primary schools had established online learning environments and most $(56 \%)$ had no plans to begin implementing them (Underwood, 2010). In Australia and New Zealand, the federally funded Learning Federation has spent millions on the development of more than 9000 curriculum based digital learning objects (Campbell \& Macnish, 2010). Over time the means of accessing these has evolved and various attempts have been made to encourage teachers' awareness of them. The degree of use of these resources is difficult to ascertain, although a study by Reimann, Freebody, Hornibrook and Howard (2009) suggests that, while appreciated by teachers, they were under-utilised.

\section{What do we know about teachers' use of the IWB and digital resources?}

Much of the research on the use of the IWB to date has focused on particular key learning areas (KLAs) or subjects. Murcia and Sheffield (2010), for example, have written in relation to the use of the IWB to support the teaching of science in three primary schools and a high school. This research found that effective IWB pedagogy impacts positively on the way students talk about science. Other researchers have 
similarly reported benefits of the IWB in the science classroom (for example Hennessy et al., 2007; Gillen, et al., 2008). The use of the IWB to support mathematical understanding has also been a focus of a number of researchers (for example, Higgins, 2010; Wood \& Ashfield, 2008), as has its use in English as a second language (Schmid, 2010).

One emerging focus for the application of IWBs has been their use to enhance communication and collaboration between the learner and the educator via video conferencing (Hinger, 2007; Saw et al., 2008). While video conferencing in not exclusive to IWB environments, McCormick (2007) has reported benefits for students in remote areas in being able to connect with, and learn from, other students. Mitchell, Hunter and Mockler (2010) found that the use of the IWB provided curriculum options for senior students in rural NSW schools.

Other research has focused on such matters as: the influence of IWBs on the pace of lessons (Higgins, et al., 2005); the interactions of participants when using the boards (Bennett \& Lockyer, 2008; Schuck \& Kearney, 2007); the multimedia affordances of the boards (Jewitt, Moss \& Cardini, 2007; Maher, 2011); their impact on student motivation (Torff \& Tirotta, 2010; Wall, Higgins \& Smith, 2005) ; their capacity to encourage and support classroom dialogue (Mercera, Hennessy \& Warwick, 2010); and the training of pre-service teachers in their use (Campbell \& Kent, 2010; Divaharan \& Koh, 2010).

Very little research, however, has investigated what resources teachers are using on their IWBs. Only a small number of studies have focused on teachers' adoption and use of digital resources more generally. For example, more than a decade ago, Mumtaz (2000) examined issues that inhibited teachers' adoption of ICT resources that included degree of experience with ICT, on-site support, ICT specialist teachers, time, access, financial support, and "teacher resistance" (related to personal and psychological factors).

More recently, Gaffney (2010) identified influential factors such as compatibility with teaching style, curriculum relevance, and the crowded curriculum and found that teachers value resources that can be directly matched to learning outcomes in the syllabus. Gaffney's research might imply that, in order for a resource to have the best chance of being chosen for use in the classroom, it needs to be presented in a way that does not require them to dramatically change their established teaching style. However, placing IWBs in classrooms itself presents a challenge to traditional teaching practices and thus may influence teachers' resource choice.

While information abounds regarding the types of digital resources available to be used with IWBs and their potential benefits, very limited empirical research has thus far focused on the resources teachers actually choose to use and what influences their decisions. In one of the few relevant studies, Kitchen, Mackenzie, Butt and Finch (2006) surveyed UK primary and secondary schools to ascertain teachers' use of a specific online curriculum website, including with their IWB. This study found that around $38 \%$ of primary teachers used Internet based digital resources in at least half their lessons in 2005, increasing from 10\% in 2002 (Kitchen et al, 2006). Key considerations influencing teachers' decisions were that they were easy to locate, they contained highly relevant content and they were suitable for the designated age ranges.

This research, then, aimed to address three questions: 
1. What digital resources do primary school teachers make use of when teaching using an IWB in their classroom?

2. What influences teachers' selection or use of such resources?

3. Are IWBs restricting or enhancing the diversity of digital resources being used in primary school classrooms?

\section{Methodology}

This study involved 13 primary Catholic schools from two Dioceses in the Australian state of New South Wales. Seven schools were drawn from a metropolitan Diocese in the Sydney area; the other six were from a rural Diocese dispersed across a $250 \mathrm{~km}$ distance. Sampling of schools was purposive with the two Diocesan educational offices nominating schools where IWBs had been in use in more than $70 \%$ of classrooms for at least 12 months. Short listing was then approached through convenience sampling, including the willingness of the school to be involved. Schools ranged in size from a small six teacher school in the rural area to a 32 teacher metropolitan school and a 34 teacher rural school.

A mixed method approach was employed, with the study collecting both quantitative and qualitative data. An online survey was developed consisting of 26 items, combining multiple choice, Likert and some open ended questions (an unformatted list of these questions is provided as Appendix 1). The invitation to complete the survey was distributed to teachers through school principals. Since participation was voluntary and communication (including reminders) was solely via the principal, response rates varied considerably between schools; $100 \%$ completion was achieved at the smallest rural school and amongst others varied from $12 \%-86 \%$ (averaging $41 \%$ ).

After completing the survey, teachers were invited to participate in a focus group to further discuss the issues. In some schools the principal actively encouraged all teachers to participate as part of a staff meeting. In others a small group of teachers met with the researcher in a lunch or tea break. A total of 10 focus groups were conducted; five metropolitan and five rural. One rural school participated in the focus group but not the survey.

Focus group discussions utilised a semi-structured interview schedule (see Appendix 2). In most instances a report on the school's survey results partially informed these discussions. Notably, all participating teachers had volunteered and thus (in some schools) may have represented a higher portion of teachers motivated by IWB and technology integration.

This paper presents both descriptive statistical data (from the survey) combined with qualitative responses (from the focus groups). In our discussion we identify a range of themes emerging from the qualitative data, consistent with a grounded theory approach (Strauss \& Corbin, 1994; Charmaz, 1993).

\section{Characteristics of participating teachers}

Of the 116 teachers who undertook the survey, 25\% were from the rural area (reflecting the smaller school sizes); $91 \%$ were female and $75 \%$ were full time permanent. Participants were drawn fairly equally from kindergarten (the first year of 
primary school) to year six; $46 \%$ had 10 years or less teaching experience and $20 \%$ had 25 years or more.

Schools were purposively sampled as those having IWBs installed in more than $70 \%$ of their classrooms. Reflective of this, $82 \%$ of responding teachers had IWBs permanently installed in their classrooms and $15 \%$ had daily access for part of the day. Teachers were asked to indicate how confident they felt using the IWB on a ten-point scale. Overall the group saw themselves as quite to very confident. Only $16 \%$ ranked themself less than 5; $13 \%$ ranked themself at 5 (i.e. the mid-way point); $24 \%$ ranked 6-7; and $37 \% 8$ and above. Six percent $(6 \%)$ rated themselves 10/10 in confidence.

\section{Findings}

In this section we present the findings from the study in relation to the three key questions:

1. What digital resources do primary school teachers make use of when teaching using an IWB in their classroom?

2. What influences teachers' selection or use of such resources?

3. Are IWBs restricting or enhancing the diversity of digital resources being used in primary school classrooms?

\section{What digital resources are teachers using?}

Firstly we will consider the data, primarily from the survey, related to

- the features of flipchart software being used;

- the extent to which teachers are using pre-made flipcharts versus creating their own;

- the use of other software applications;

- the use of online resources; and

- the use of peripheral devices.

Features of flipchart software being used

The survey asked teachers to indicate how often they used a range of features of their flipchart software on a three-point scale (with $1=$ never and $3=$ frequently) and to differentiate how often they used the features for both preparing lessons and using the whiteboard in the classroom with students. Responses are presented in Table 1.

One of the most frequent uses of flipchart software in lesson preparation was thus to link to other documents or websites and to display gallery objects and multimedia files demonstrating that teachers are making significant use of 'other' resources (via galleries and online) to support their lessons. In their use of IWBs with students, not surprisingly, the writing/drawing capabilities of the board are frequently used. Handwriting recognition is seldom used (33\% never use and $46 \%$ occasionally use) and the recording function (which enables a lesson to be played back), also was underutilised ( $82 \%$ never using it; $2 \%$ frequently using it). 
Table 1: Use of features of flipchart software for preparing and implementing lessons

( 1 = Never; 2 = Occasionally; 3 = Frequently $)$

\begin{tabular}{|c|c|c|c|c|c|c|c|c|c|c|}
\hline \multirow{2}{*}{$\begin{array}{l}\text { Flipchart software } \\
\text { features used }\end{array}$} & \multicolumn{5}{|c|}{$\begin{array}{l}\text { Preparing lessons } \\
\quad(n=94-98)\end{array}$} & \multicolumn{5}{|c|}{$\begin{array}{l}\text { Implementing lessons } \\
(\mathrm{n}=98-103)\end{array}$} \\
\hline & $\mathrm{N}$ & Never & $\begin{array}{l}\text { Occa- } \\
\text { sion- } \\
\text { ally }\end{array}$ & $\begin{array}{l}\text { Fre- } \\
\text { que- } \\
\text { ntly }\end{array}$ & Mean & $\mathrm{N}$ & Never & $\begin{array}{l}\text { Occa- } \\
\text { sion- } \\
\text { ally }\end{array}$ & $\begin{array}{l}\text { Fre- } \\
\text { que- } \\
\text { ntly }\end{array}$ & Mean \\
\hline $\begin{array}{l}\text { Writing/ drawing on multip- } \\
\text { le screens or "flipcharts" (like } \\
\text { a conventional chalkboard) }\end{array}$ & 97 & $20 \%$ & $53 \%$ & $28 \%$ & 2.08 & 102 & $8 \%$ & $39 \%$ & $53 \%$ & 2.45 \\
\hline $\begin{array}{l}\text { Objects, images, or the clip } \\
\text { art gallery including inter- } \\
\text { active objects such as dice }\end{array}$ & 95 & $13 \%$ & $57 \%$ & $31 \%$ & 2.18 & 101 & $6 \%$ & $49 \%$ & $46 \%$ & 2.40 \\
\hline $\begin{array}{l}\text { Character / hand-writing } \\
\text { recognition }\end{array}$ & 97 & $52 \%$ & $35 \%$ & $13 \%$ & 1.62 & 102 & $33 \%$ & $46 \%$ & $21 \%$ & 1.87 \\
\hline $\begin{array}{l}\text { Multimedia elements such as } \\
\text { video, audio, or Flash files } \\
\text { from the provided gallery }\end{array}$ & 98 & $17 \%$ & $47 \%$ & $36 \%$ & 2.18 & 103 & $14 \%$ & $45 \%$ & $42 \%$ & 2.28 \\
\hline $\begin{array}{l}\text { Use of colour, shading and/ } \\
\text { or highlighting for emphasis }\end{array}$ & 96 & $22 \%$ & $43 \%$ & $35 \%$ & 2.14 & 103 & $15 \%$ & $39 \%$ & $47 \%$ & 2.32 \\
\hline $\begin{array}{l}\text { Screen capture (e.g. from a } \\
\text { website) to your flipchart }\end{array}$ & 95 & $34 \%$ & $44 \%$ & $22 \%$ & 1.88 & 98 & $32 \%$ & $49 \%$ & $19 \%$ & 1.88 \\
\hline $\begin{array}{l}\text { Linking to other documents } \\
\text { or websites }\end{array}$ & 97 & $20 \%$ & $38 \%$ & $42 \%$ & 2.23 & 100 & $18 \%$ & $42 \%$ & $40 \%$ & 2.22 \\
\hline $\begin{array}{l}\text { Storing or embedding other } \\
\text { resources in your flipchart } \\
\text { file. }\end{array}$ & 97 & $41 \%$ & $43 \%$ & $15 \%$ & 1.74 & 100 & $40 \%$ & $48 \%$ & $12 \%$ & 1.72 \\
\hline
\end{tabular}

Use of ready-made flipcharts

Many flipchart software manufacturers produce ready-made lessons that can be downloaded from the IWB company sites (e.g. from Promethean Planet or SMART Exchange). Table 2 indicates how frequently such resources were being used and the extent to which teachers created their own resources and shared them with other teachers.

Table 2: Use of ready-made flipcharts versus creation of such resources $(n=102)$ ( 1 = Never; 2 = Occasionally; 3 = Frequently $)$

\begin{tabular}{|c|c|c|c|c|}
\hline & Never & $\begin{array}{l}\text { Occas- } \\
\text { ionally }\end{array}$ & $\begin{array}{c}\text { Frequ- } \\
\text { ently }\end{array}$ & Mean \\
\hline $\begin{array}{l}\text { Use pre-made IWB lessons downloaded by you or } \\
\text { your colleagues }\end{array}$ & $16 \%$ & $63 \%$ & $21 \%$ & 3.10 \\
\hline Search online for pre-made IWB lessons or resources & $12 \%$ & $60 \%$ & $28 \%$ & 3.33 \\
\hline Modify pre-made lessons before using them & $27 \%$ & $51 \%$ & $22 \%$ & 2.88 \\
\hline Create your own IWB lessons & $17 \%$ & $43 \%$ & $40 \%$ & 3.47 \\
\hline $\begin{array}{l}\text { Create your own IWB lessons and share them with } \\
\text { your colleagues }\end{array}$ & $28 \%$ & $46 \%$ & $26 \%$ & 2.94 \\
\hline Create your own IWB lessons and share them online & $91 \%$ & $7 \%$ & $2 \%$ & 1.22 \\
\hline
\end{tabular}

While many teachers did make occasional or frequent use of pre-made resources, it is significant that considerably more were frequently creating their own rather than using pre-made ones and many who did locate resources online modified them to some extent. The reasons are discussed later in this paper. Of those creating their own, only $26 \%$ frequently shared these with colleagues ( $46 \%$ occasionally did) but very few (9\%) shared them online. 
Use of other applications

Teachers were asked how frequently they used a range of other software resources with their IWB (with $1=$ never and 3 = frequently). Table 3 presents these in order from most to least frequently used.

Table 3: Use of various applications on IWBs $(n=97-100)$

\begin{tabular}{|c|c|c|c|c|}
\hline Application & Never & $\begin{array}{l}\text { Occas- } \\
\text { ionally }\end{array}$ & $\begin{array}{l}\text { Frequ- } \\
\text { ently }\end{array}$ & Mean \\
\hline Word processor (e.g. Microsoft Word) & $4 \%$ & $34 \%$ & $61 \%$ & 2.58 \\
\hline Presentation software (e.g. PowerPoint) & $8 \%$ & $45 \%$ & $46 \%$ & 2.38 \\
\hline General puzzles or games & $14 \%$ & $47 \%$ & $39 \%$ & 2.25 \\
\hline $\begin{array}{l}\text { Specific commercial software to support curriculum (e.g. } \\
\text { phonics, maths or science software typically on CD) }\end{array}$ & $36 \%$ & $38 \%$ & $25 \%$ & 1.89 \\
\hline Mind mapping software (e.g. Inspiration or Kidspiration) & $40 \%$ & $37 \%$ & $23 \%$ & 1.83 \\
\hline $\begin{array}{l}\text { Learning objects (such as the Learning Federation } \\
\text { resources or other Flash resources online) }\end{array}$ & $41 \%$ & $34 \%$ & $23 \%$ & 1.82 \\
\hline Drawing or painting software (e.g. Paint) & $35 \%$ & $54 \%$ & $11 \%$ & 1.76 \\
\hline $\begin{array}{l}\text { Photo or video editing software (e.g. Photoshop, } \\
\text { MovieMaker) }\end{array}$ & $51 \%$ & $42 \%$ & $7 \%$ & 1.57 \\
\hline Spreadsheet (e.g. Microsoft Excel) & $52 \%$ & $40 \%$ & $7 \%$ & 1.55 \\
\hline Multimedia 'publishing' software (e.g. Kidspix) & $62 \%$ & $32 \%$ & $6 \%$ & 1.44 \\
\hline Digital encyclopaedias & $63 \%$ & $34 \%$ & $3 \%$ & 1.40 \\
\hline Animation or 3D software (e.g. Kahootz) & $79 \%$ & $20 \%$ & $1 \%$ & 1.22 \\
\hline $\begin{array}{l}\text { Database software (e.g. Access, Filemaker, 2Investigate, } \\
\text { MaxData) }\end{array}$ & $87 \%$ & $12 \%$ & $1 \%$ & 1.14 \\
\hline Music writing software & $92 \%$ & $6 \%$ & $2 \%$ & 1.10 \\
\hline
\end{tabular}

Contrary to our initial expectations, traditional office applications remained frequently used on the IWB, although some respondents may have been referring to use of Word (for example) to prepare flipcharts or to demonstrate use to students, as discussed later in this paper.

Table 4: Use of online resources $(n=98-100)$

\begin{tabular}{|c|c|c|c|c|}
\hline Online resource & Never & $\begin{array}{l}\text { Occas- } \\
\text { ionally }\end{array}$ & $\begin{array}{l}\text { Frequ- } \\
\text { ently }\end{array}$ & Mean \\
\hline $\begin{array}{l}\text { Search engines (e.g. Google, Yahoo) to search for } \\
\text { information or resources with your students) }\end{array}$ & $6 \%$ & $27 \%$ & $67 \%$ & 2.61 \\
\hline Online pictures/still images & $3 \%$ & $36 \%$ & $61 \%$ & 2.58 \\
\hline $\begin{array}{l}\text { Online video clips or streaming TV (e.g. from YouTube or } \\
\text { Teacher Tube) }\end{array}$ & $7 \%$ & $47 \%$ & $46 \%$ & 2.39 \\
\hline $\begin{array}{l}\text { Informational web pages that you locate before the lesson } \\
\text { as a source of information }\end{array}$ & $13 \%$ & $41 \%$ & $45 \%$ & 2.32 \\
\hline $\begin{array}{l}\text { Flash animations / games / learning objects (i.e. interactive } \\
\text { multimedia resources) }\end{array}$ & $15 \%$ & $40 \%$ & $45 \%$ & 2.30 \\
\hline Mapping software (e.g. Google Earth) & $47 \%$ & $47 \%$ & $6 \%$ & 1.59 \\
\hline Your own class web page or site (if you have one) & $61 \%$ & $30 \%$ & $8 \%$ & 1.46 \\
\hline Your school website & $42 \%$ & $43 \%$ & $14 \%$ & 1.72 \\
\hline Online audio files (podcasts) & $44 \%$ & $47 \%$ & $8 \%$ & 1.64 \\
\hline Wikis & $62 \%$ & $28 \%$ & $9 \%$ & 1.46 \\
\hline Other schools' websites & $61 \%$ & $34 \%$ & $5 \%$ & 1.44 \\
\hline Learning platforms (e.g. Moodle, MyClasses) & $65 \%$ & $27 \%$ & $8 \%$ & 1.43 \\
\hline Blogs & $67 \%$ & $30 \%$ & $2 \%$ & 1.34 \\
\hline Text, voice or video chat (e.g. Skype) & $88 \%$ & $11 \%$ & $0 \%$ & 1.11 \\
\hline Social networking sites (e.g. Facebook) & $97 \%$ & $3 \%$ & $0 \%$ & 1.03 \\
\hline
\end{tabular}


Use of online resources

Teachers were asked to indicate how frequently they used a range of online resources with their IWB. Responses are summarised in Table 4, from most to least frequently used.

Setting aside the high use of search engines, multimedia resources were evidently most popular. Data indicates, however, that online communication (both synchronous and asynchronous) is not playing a role in the IWB teaching patterns of most teachers.

Use of other peripheral hardware

The survey also asked teachers to indicate whether (and how often) they used peripheral devices. Data are presented in Table 5.

Table 5: Use of peripheral hardware $(\mathrm{n}=100-101)$

\begin{tabular}{|l|c|c|c|c|}
\hline \multicolumn{1}{|c|}{ Hardware } & Never & $\begin{array}{c}\text { Occas- } \\
\text { ionally }\end{array}$ & $\begin{array}{c}\text { Frequ- } \\
\text { ently }\end{array}$ & Mean \\
\hline Standard DVDs & $11 \%$ & $62 \%$ & $27 \%$ & 2.16 \\
\hline A scanner to digitise text or images & $50 \%$ & $36 \%$ & $14 \%$ & 1.64 \\
\hline Videos available via a school network & $55 \%$ & $40 \%$ & $5 \%$ & 1.51 \\
\hline A visualiser (e.g. to display pages of a book) & $66 \%$ & $25 \%$ & $9 \%$ & 1.43 \\
\hline A webcam & $78 \%$ & $21 \%$ & $1 \%$ & 1.23 \\
\hline Digital microscopes & $86 \%$ & $13 \%$ & $1 \%$ & 1.15 \\
\hline Learner response systems (e.g. ActivVote) & $89 \%$ & $8 \%$ & $3 \%$ & 1.14 \\
\hline Tablet PCs or slates & $91 \%$ & $8 \%$ & $2 \%$ & 1.12 \\
\hline
\end{tabular}

While not all teachers would have had access to the above mentioned hardware it is still interesting that, with the exception of standard DVDs, use of such peripheral devices was generally very low. Even when considering equipment such as scanners and webcams (which are more widely used), 50\% and 78\% (respectively) of teachers never use such resources. Learner response systems, which have been widely marketed for use with IWBs, have not gained widespread use in these schools with close to $90 \%$ of teachers never using such devices.

\section{What influences teachers' selection and use of resources?}

In this section we discuss what influences teacher's selection and/or use of various resources on their IWBs. Survey data provides an overview of these influences, which were explored in more depth in the focus groups. The survey sought to understand these issues in two ways; firstly through an open question (thus minimising influence on responses) and secondly through Likert-scale responses to pre-identified factors.

The open response question asked teachers what they saw as the most influential factor/s impacting on their choice of digital resources. Common themes were identified and the number of teachers mentioning each issue tallied (teachers could mention more than one issue). Results are presented in Table 6.

Table 7 indicates teachers' responses about pre-identified factors influencing their awareness of available resources and Table 8 indicates what influences their decision to use resources (with $1=$ not influential and $3=$ very influential). 
Table 6: Factors influencing choice of resources (themes from open response)

\begin{tabular}{|l|c|l|c|}
\hline \multicolumn{1}{|c|}{ Issue } & $\begin{array}{c}\text { Number of } \\
\text { mentions }\end{array}$ & \multicolumn{1}{|c|}{ Issue } & $\begin{array}{c}\text { Number of } \\
\text { mentions }\end{array}$ \\
\hline Ease/simplicity of use & 20 & Content & 4 \\
\hline Accessibility/availability & 19 & Quality & 3 \\
\hline $\begin{array}{l}\text { Perceived benefit to students/ } \\
\text { needs of students }\end{array}$ & 12 & Visuals & 4 \\
\hline Relevance to curriculum/topic & 10 & Prior exposure/familiarity & 2 \\
\hline Reliability & 9 & Group work & 2 \\
\hline Training/ in-servicing & 9 & $\begin{array}{l}\text { Motivational/ engaging for } \\
\text { students }\end{array}$ & 1 \\
\hline $\begin{array}{l}\text { Appropriateness for age/ability of } \\
\text { tudents }\end{array}$ & 8 & Colleagues & 1 \\
\hline Time (e.g. to use or plan/prepare) & 8 & Flexibility & 1 \\
\hline Interactivity & 6 & & \\
\hline
\end{tabular}

Table 7: Factors influencing teachers' awareness of resource availability (n=98-99)

\begin{tabular}{|l|c|c|c|c|}
\hline \multicolumn{1}{|c|}{ Awareness factor } & $\begin{array}{c}\text { Not at all } \\
\text { influential }\end{array}$ & $\begin{array}{c}\text { Somewhat } \\
\text { influential }\end{array}$ & $\begin{array}{c}\text { Very } \\
\text { influential }\end{array}$ & Mean \\
\hline $\begin{array}{l}\text { Seeing your colleagues using it or having it } \\
\text { recommended by them }\end{array}$ & $0 \%$ & $20 \%$ & $80 \%$ & 2.80 \\
\hline $\begin{array}{l}\text { Seeing it used at an in-service/ professional } \\
\text { development session }\end{array}$ & $2 \%$ & $36 \%$ & $62 \%$ & 2.60 \\
\hline You found it yourself when searching & $6 \%$ & $47 \%$ & $47 \%$ & 2.40 \\
\hline It was already available on the computer or network & $8 \%$ & $47 \%$ & $45 \%$ & 2.36 \\
\hline $\begin{array}{l}\text { Your principal or other school leader recommending } \\
\text { it }\end{array}$ & $7 \%$ & $57 \%$ & $36 \%$ & 2.29 \\
\hline Your students recommending it & $10 \%$ & $61 \%$ & $29 \%$ & 2.19 \\
\hline Reading about it in a magazine & $28 \%$ & $67 \%$ & $5 \%$ & 1.77 \\
\hline
\end{tabular}

Table 8: Factors influencing teachers' decision to use resources on their IWB (n=97-98)

\begin{tabular}{|l|c|c|c|c|}
\hline \multicolumn{1}{|c|}{ Resources factor } & $\begin{array}{c}\text { Not at all } \\
\text { influential }\end{array}$ & $\begin{array}{c}\text { Somewhat } \\
\text { influential }\end{array}$ & $\begin{array}{c}\text { Very } \\
\text { influential }\end{array}$ & Mean \\
\hline The students will be motivated to learn with it & $0 \%$ & $13 \%$ & $87 \%$ & 2.87 \\
\hline $\begin{array}{l}\text { You believe it will help cater for different student } \\
\text { needs (e.g. abilities or learning styles) }\end{array}$ & $1 \%$ & $20 \%$ & $79 \%$ & 2.78 \\
\hline It is already installed & $3 \%$ & $33 \%$ & $64 \%$ & 2.61 \\
\hline You like to try new teaching ideas & $0 \%$ & $34 \%$ & $66 \%$ & 2.66 \\
\hline You want to be seen using your IWB & $49 \%$ & $40 \%$ & $11 \%$ & 1.62 \\
\hline
\end{tabular}

From this data we can ascertain that recommendation, either formally through professional development sessions or informally through word of mouth, is most influential on teachers' awareness of available resources, although school leaders were not as influential. Of interest to resource manufacturers and distributors, magazines played a very small role. Decisions to use a resource were highly student focused with motivation and differentiation playing a strong role.

Focus group discussions provided an opportunity to explore in greater detail the above data and a range of themes are presented in the remainder of this section. 
Key resource websites and word of mouth

Particular websites were popular amongst teachers and were discussed both within and between schools. As a teacher at School M indicated, "Finding good sites where resources are already grouped together well is valuable". In some instances there was overlap between those widely used in the rural and regional systems, but also notably differences. Mathletics (http://www.mathletics.com.au/) and the Copacabana Public School Get Smart site (http:/ / www.copacabana-p.schools.nsw.edu.au/Get_Smart_ Pages/Get_Smart.htm), for example, were well known in both regions. The Jenny Eather site (http://www.writingfun.com/), however, was mentioned by teachers at many metropolitan schools, but only one of the rural schools and Smartkiddies (now called Studyladder, http: / / www.studyladder.com.au/) was mentioned consistently by rural teachers but not metropolitan ones.

Initiatives within a school sector were evidently influential on resource use. In the rural Diocese a series of annual IWB "conferences" had played a key role in disseminating knowledge about IWB resources. Recent professional development had also influenced use of the Skootle site (Skootle provides a web interface and search functionality for the Learning Federation learning objects, allowing teachers to construct "learning paths" which students access via a unique student pin http://www.scootle.edu.au/). In the metropolitan area Skootle wasn't discussed although the creation of a Ning by teacher librarians was mentioned.

Sharing resources between teachers within a school

Considerable differences were detected in the cultures within various schools regarding the exchange of resources. The creation, modification and sharing of flipchart resources, for example, was very strong amongst the staff at School B and C but less so at other schools. School B had organised "Promethean Parties" where they would meet with teachers from other schools to swap resources then continue these personal networks through online interaction. This school also scheduled regular time at staff meetings for such sharing. In contrast, School $\mathrm{E}$ teachers indicated an unwillingness to spend time developing or modifying flipcharts and, because they remained less than satisfied with existing ones, they did not save or refer others to them.

Sharing mostly occurred at a stage level, where teachers were covering the same curriculum. Different schools had different processes in place. In some sharing was done informally (via word of mouth and email), whereas in other schools formal processes were in place. Many rural schools had established a directory on their school server where teachers could save flipchart files: "Everything we make we save on the Intranet and organise in year and then into KLAs and then those are broken down into strands" (School C). At other schools the process was more "haphazard" (School D). No metropolitan schools mentioned such strategies, although School L referred to a blog for "sharing technology ideas".

Only one teacher (from School B) described how she had uploaded flipchart resources to Promethean Planet, noting that "the process is quite cumbersome and sometimes you just get frustrated... so you don't bother". A clue as to teachers' general hesitancy to share resources via such online sites can be gleaned from one participant's selfconscious remark that while willing to share she was worried whether they were "good enough". 


\section{Student engagement and interactivity}

A key consideration for teachers in selecting resources was the degree of interactivity they provided: "... the ones that get a big tick are the ones that the kids can get up and push and drag. It's that interactive nature that transforms (the IWB) from being a data projector to a learning tool" (School I). Such motivational and fun resources were viewed as useful for transitions: "When we have five minutes to spare or we are coming in from recess or lunch I put something on the board to refocus them" (School K). A teacher from School B provided a good example, describing a lesson about Ned Kelly (an Australian folk hero). She had accessed a YouTube video with the story depicted by Lego characters; "they just loved it and... they all took everything in. They really understood the story and I do think that since it was told by Lego characters had a lot to do with that". This teacher also described how digital resources could help compensate for gaps in her own skills:

\footnotetext{
For me, dance is not a strong point so you turn on YouTube and just point the kids at the screen and I practise down the back. The other day we were doing 'I like to move it move it' from the Madagascar movie. Now for me to make up that sequence, I wouldn't have had a clue! The sequence was there and I didn't have to choreograph (School B).
}

Teachers recognised that older children in particular did not want to watch others using the IWB for too long or they would get bored, so the IWB was used to demonstrate a site which students would access themselves via laptops or desktops or via the IWB as a small group activity (see following point).

\section{Suitability for small group work}

A number of teachers indicated that they chose resources which students could use as a small group activity. A number of schools in both regions (C, J and $\mathrm{M}$ ) were implementing open plan classes, with multiple teachers and 'classes' using a large space. IWBs were viewed as one of the activity stations which students circulate around. In such instances it was seen as beneficial to access interactive sites, "the ones that kids can actually use and manipulate are better for group work" (School G). As an example, a teacher at School I discussed using Spelling City, which enabled her to enter a list of words and generate activities based on those words: "... if you use it in groups with 4 or 5 children then they all get to have a turn quickly then they all stay focused on the activity and they learn with and from each other". A teacher at School K elaborated that they used both mixed and matched ability groupings and so would choose resources most appropriately for group composition.

Suitability of resources to the students' specific needs

A key consideration for many was the suitability of the resource to the specific needs of students. Pre-made flipchart lessons, for example, were often described as not entirely suitable, for example they may not provide enough examples, or the examples might be too easy or too hard. Teachers spoke of preferring sites where resources of increasing levels of difficulty were available, so activities could be differentiated.

Ability of the resource to be used independently by students

Related to the above, teachers also sought resources that students could use in a semiautonomous way, such that they could be provided to a student who may need additional practice to reinforce learning. In choosing such resources it was beneficial if the teacher could go back and check what the student had done. Sites with levels that 
children progress through were valued. In such instances, the IWB was used to demonstrate the resource that students might then interact with independently.

Safety and reliability in linking students to resources

Given the above priorities (student independence and group work) an important consideration for some teachers was the means by which they could 'link' students to required resources. At School G and I, for example, teachers spoke of using either a class or a school curriculum wiki as a 'launchpad' for students and staff to access and re-access resources. Teachers with older classes, however, indicated that students searched for resources themselves, and this was viewed as an opportunity to model good searching skills and encourage self directed learning; "it is just so easy and quick to search and find things again that why would you bother to link to them. It is good for the kids to see how you find things" (School M). Related to this were teachers' concern about the reliability and 'safety' of a resource site. Teachers at School G, for example, downloaded YouTube videos "because, especially with younger students, we don't want them to click on other links".

There was a recognisable 'trend' toward sites that enabled teachers to structure resources (such as learning objects) into a learning sequence for students to complete in class or as homework (e.g. Skootle and Studyladder). School D liked Studyladder because it "only allows them to do 1 hour a day [homework] so they can't do too much". This led to a discussion of students' initial enthusiasm with Mathletics, where students would spend hours doing mathematics each evening and teachers reflected that the same was happening with Reading Eggs.

\section{'Australian-ness'}

Teachers were very conscious of the dominance of US and UK resources, particularly in regard to pre-made flipchart lessons. They spoke of having difficulty finding suitable Australian resources and needing to modify flipchart lessons to make them more appropriate, for example to reflect Australian spellings, substitute the use of Australian images or to include appropriate units of currency or measurement. It is significant that almost all of the most popular online resources (such as Jenny Ether's Writing Fun, Studyladder, ABC Reading Eggs and the Copacabana Writing Fun sites) were Australian.

Reducing repetition for students across years

A theme arising in focus groups was the need to ensure that a particular resource was not over-used with students. School D had an explicit strategy in place whereby certain resources were designated for use in particular years/stages; "The kids get sick of it otherwise". School J mentioned this repetition as a factor influencing their decisions to purchase resources for IWB use.

Online versus installed

There was clearly an established preference for online resources rather than those needing to be installed on the school network: "you can access it from anywhere, don't have to wait for the system administrator to come and install it ... which could take weeks" (School B). Teachers perceived major benefits in being able to access the resource at home for lesson planning but were also wary about resources that might not work in the school environment (e.g. if the browser or Flash hasn't been updated). Several spoke of the speed by which they could find a resource and "convince the principal to subscribe" (School B) such that it could be accessed almost immediately. 


\section{Paid versus free}

Teachers at a number of schools discussed the influence of cost on resource choice. A number of companies had began by making their resources freely available and then, once use escalated, introduced a fee. For some schools the imposed price was a major deterrent. and schools needed to make considered choices about which resources they did and did not subscribe to, being highly conscious of value for money. A number of online sites were viewed as well worth the investment, where they made life easier for teachers, actively engaged students and improved learning outcomes.

\section{Navigation and searchability}

Ease of navigation and searchability were also important. One teacher, for example, described difficulties accessing Learning Federation learning objects; "Searching for 'narrative', nothing would come up. There are 100s there that are suitable but it takes an extra hour to search through everything". Sites that required passwords from students presented some challenges, although these were not viewed as deterrents and generally it was felt that students could remember their logins providing teachers had a backup list.

\section{Time and training}

While time is often cited as a major issue for teachers, in this study, it was not viewed as a major deterrent to digital resource use. Teachers mostly saw resources as a timesaver although some did mention spending a lot of their own time locating them. There were mixed views across schools about the efficiency of creating flipchart lessons, with teachers at School B indicating that it was quicker to create them, while at School $\mathrm{E}$ the dominant sentiment was that even modifying flipcharts was too time consuming: "You're wasting your time big time if you put in hours and hours for 5 mins worth of class time" (School E). It was acknowledged, however, that skills and training were an issue at this school and that by avoiding doing so they weren't getting practice. This is consistent with data from other schools where teachers indicated that they became more efficient in creating flipcharts the more they did it.

\section{Are IWBs restricting or enhancing the diversity of ICT applications being used?}

As highlighted earlier, teachers can sometimes be led to believe that only specific software can be used on an IWB, and so this study was interested to ascertain whether IWBs were restricting or enhancing the diversity of software being used. Overall, the study revealed a diversity of digital resources in use. Primarily, the resources were interactive, online ones (as discussed above) but there was also evidence of teachers integrating a wider range including CD software such as Kahootz (3D animation) and PM Story Books, traditional DVDs, flip cameras, and claymation. There were perceived benefits of the large IWB display for engaging the whole class with these resources.

That stated, evidence was still presented of the susceptibility of teachers to marketing strategies that emphasise IWB compatibility. The comment "We think about what software will run on the computer rather than the IWB" (School J) might be contrasted with the following; "I noticed in a catalogue the other day that there is more and more software becoming available that you can use on the IWB so it is a matter of the school investing more money in that type of thing" (School I).

We were also particularly interested to ascertain whether flipchart software was reducing or replacing other traditional Microsoft Office applications. The study 
indicated that such applications were still used by both teachers and students, although perhaps in different or reduced ways. Teachers generally would not use word processors for lessons unless they were demonstrating specific skills, and flipchart software was viewed as playing the main role in displaying and manipulating texts on the IWB. However, a number of teachers noted that they would use Word to type up a document before importing it into the flipchart because it was easier and quicker for typing.

Interesting discussions were held regarding presentation programs. While Microsoft PowerPoint and Open Office Presentation were still used in schools (such as for parent information nights, or by students at home or on their laptops) there was evidence in both school systems of teachers preferring to use other software such as Keynote (School G) or Web 2.0 tools such as Prezi (School C and L). Data indicated low levels of spreadsheet and database use, despite such applications having been part of an ICT scope and sequence document in the rural Diocese for many years. The trend toward interactive and online resources is well reflected in the following teacher's comment: "I have used excel before for spreadsheets but whenever you use office products it's not really interactive for the kids. It's just using it for presentation" (School G).

\section{Discussion}

This study suggests that the use of IWBs in classrooms is enhancing rather than restricting the diversity of digital resources being used in primary classrooms. That said, IWBs are placing an increased emphasis on online interactive and multimedia resources (such as learning objects, puzzles and games, images and movies). Schools are most likely to pay for online resources that can be flexibly accessed by students at school and at home and which provide 'value for money'.

There was a fairly equal distribution of teachers using pre-existing flipchart lessons and those creating their own. Teachers with more experience with this software (influenced, no doubt, by higher motivation and interest) were more likely to be critical about the quality of pre-made lessons and to recognise the efficiencies in modifying or creating lessons from scratch. Word processors and presentation software are still used by teachers and students and flipchart software was generally seen as an addition rather than an alternative tool.

Gaffney (2010) identified that the decisions teachers' make regarding resources is a very complex process based on a range of factors, the most important being compatibility with teaching style and relevance to the curriculum. This study would support these claims but also indicates that, in an IWB environment, innovative and creative teachers are adapting their board and other digital resources to match their pedagogical inclinations. Far from placing a greater emphasis on whole-class instruction, the study revealed a renewed focus on resources that could be used by students in small groups or to support self-directed learning. IWBs were finding an important role in "open classrooms" and in group rotation sessions, and for demonstrating tasks for students to complete on laptops, in labs or at home. These findings are consistent with Higgins et al (2005) who concluded that the use of IWBs for group work is likely to increase with the advent of boards that allow two and three users to interact at once. There are implications here for resource developers who may find benefits in developing resources specifically for small group use. 
This study documents a diversity of resource use, and also shows "trends" in popularity and use, within and between schools, spread through both formal and informal channels. Clearly, word of mouth was a powerful influence on resource choice and professional development opportunities were important sources of information about new and beneficial resources. That stated, teachers did enjoy the independence of being able to locate resources that they believed 'fitted' with their planned lessons and teaching style and (again) online resources provided such flexibility. While there were few examples of these teachers using resources such as VLEs (with the exception of one school using KnowledgeNet) it was evident that sites which facilitated the sequencing of resources, if easy to use, were likely to gain increased popularity.

This study supports Lee and Winzenried's (2009) observation that, to be widely used, resources need to be easily accessible, clearly labelled (through good metadata) and relevant to students' learning needs. Resources designed to meet specific elements of the curriculum were highly valued and sites that organise resources according to curriculum themes and topics are very popular. Australian resources were particularly valued. With the advent of the new National Curriculum in Australia, at least one teacher recognised the potential for a national initiative to compile resources to meet new requirements. There will clearly also be a need to structure and present existing resources, such as The Learning Federation digital resources, to link more strongly with the new curriculum requirements.

Just as important as our understanding of what resources are being used are our insights into what resources are under-utilised. Clearly, very little use is being made of communication tools such as blogs, wikis or video/audio conferencing possibilities. Global projects of the type advocated for use in classrooms since the 1980s, for instance by Judy Harris (2008), are not being embraced by teachers, despite the now enhanced diversity of communication technologies available to facilitate such learning experiences.

There is clearly much opportunity for further research related to teachers' digital resource use. Since this study has provided evidence that the prevailing teacher culture can profoundly impact on the resources used, it would be interesting to compare and contrast this Australian study's findings with other countries, particularly in non-English speaking and non-western countries where IWBs are rapidly increasing in use, but where nationally and linguistically relevant resources may be in shorter supply.

\section{Conclusions}

As more IWBs are installed in classrooms, teachers will increasingly switch to a more digital based mode of teaching and learning. Their choice of resources will directly influence the type of learning experiences that children are exposed to.

This study has important implications for teachers themselves, school leaders, school systems and teacher educators. School leaders are frequently the ones involved in resource purchase decisions. This study has demonstrated that quality Australian resources are available and that teachers using such resources feel that those with a cost involved do valuably supplement those freely available. Provision of time for teacher learning is, as is often the case, key to enhancing awareness and appropriate 
selection of resources. Professional development, whether provided at school or school system level, should provide opportunities for teachers to engage in dialogue and share experiences about what resources they use and how they use them. The importance of sharing pedagogical strategies should also occur side by side with discussion of resources themselves since there are many good examples of IWBs not just being used for teacher-directed lessons. Conversations about how IWBs can be productively used to support constructivist and student-centred pedagogy are essential.

Teacher educators might note the importance of providing opportunities for preservice teachers to interact with and learn to critique the resources being used in schools. Training for use of IWBs is part of this picture and there were a number of early-career teachers interviewed who had received minimal exposure to IWBs at university. However, teacher education needs to emphasise that it is not just the IWB that makes a difference to student learning outcomes. Rather, it is how the board is used pedagogically, and the digital resources selected, which are important.

Perhaps most significantly, the study carries a number of important implications for governmental and commercial producers of digital resources. Teachers need to be able to locate resources quickly and easily and the metadata used to support searching needs to be well targeted to curriculum requirements. While international resources abound, the study has demonstrated a keen interest by Australian teachers in Australian resources - those that most closely link with required curriculum. The new National curriculum provides an opening for government or commercial organisations to leap into this gap.

\section{References}

Becta (2009). Harnessing technology for next generation learning: Children, schools and families implementation plan 2009-2012. http:/ / webarchive.nationalarchives.gov.uk/ 20101102103654/http:/ / publications.becta.org.uk/download.cfm?resID=39547

Bennett, S. \& Lockyer, L. (2008). A study of teachers' integration of interactive whiteboards into four Australian primary school classrooms. Learning, Media and Technology, 33(4), 289-300. http: / / dx.doi.org/10.1080/17439880802497008

Campbell, C. \& Kent, P. (2010). Using interactive whiteboards in pre-service teacher education: Examples from two Australian universities. In M. Thomas \& A. Jones (Eds), Interactive whiteboards: An Australasian perspective. Australasian Journal of Educational Technology, 26(Special issue, 4), 447-463. http:/ / www.ascilite.org.au/ ajet/ ajet26/ campbell.html

Campbell, C. \& Macnish, J. (2010). Pre-service teachers using The Le@rning Federation's digital resources. Paper presented ED-MEDIA: World Conference on Educational Multimedia, Hypermedia and Telecommunications. Toronto, Canada, 28 June-2 July, 2010. http: / / researchonline.nd.edu.au/cgi/ viewcontent.cgi?article=1022\&context=edu_conference

Charmaz, K. (1993). The grounded theory method: An explanation and interpretation. In R.Emerson (Ed.), Contemporary field research. Boston, Mass: Little Brown.

Divaharan, S. \& Koh, J. H. L. (2010). Learning as students to become better teachers: Pre-service teachers' IWB learning experience. In M. Thomas \& A. Jones (Eds), Interactive whiteboards: An Australasian perspective. Australasian Journal of Educational Technology, 26(Special issue, 4), 553-570. http: / / www.ascilite.org.au/ajet/ajet26/divaharan.html 
Futuresource Consulting (2010a). 1 million interactive whiteboards will be sold in 2010 according to new Futuresource report. Press release. [viewed 2 Aug 2010, verified 10 Jan 2012] http:/ / www.futuresource-consulting.com/pdfs/2010-02_IWB_release.pdf

Futuresource Consulting (2010b). Projector and interactive whiteboard usage in primary and secondary schools. [viewed 4 Aug 2010, verified 10 jan 2012] http: / / www.futuresourceconsulting.com/ press / 2010-05\%20Projector+IWB \%20WhitePaper.pdf

Gaffney, M. (2010). Enhancing teachers' take-up of digital content: Factors and design principles in technology adoption. [viewed 2 Sep 2010, verified 10 Jan 2012; $5.6 \mathrm{MB}$ ] http: / / www.ndlrn. edu.au/verve/_resources/Enhancing_Teacher_Takeup_of_Digital_Content_Report.PDF

Gillen, J., Littleton, K., Twiner, A., Staarman, J. \& Mercer, N. (2008). Using the interactive whiteboard to resource continuity and support multimodal teaching in a primary science classroom. Journal of Computer Assisted Learning, 24(4), 348-358. http: / / dx.doi.org/10.1111/j.1365-2729.2007.00269.x

Hall, I. \& Higgins, S. (2005). Primary school students' perceptions of interactive whiteboards. Journal of Computer Assisted Learning, 21(2), 102-117. http: / / dx.doi.org/10.1111/j.13652729.2005.00118.x

Harris, J. B. (2008). TPCK in in-service education. Assisting experienced teachers' "planned improvisations". In AACTE Committee on Innovation and Technology (Ed.), Handbook of technological pedagogical content knowledge (TPCK) for educators. 251-271. Milton Park, UK: Routledge.

Hennessy, S., Deaney, R., Ruthven, K. \& Winterbottom, M. (2007). Pedagogical strategies for using the interactive whiteboard to foster learner participation in school science. Learning, Media and Technology, 32(3), 283-301. http: / / dx.doi.org/10.1080/17439880701511131

Higgins, S. E. (2010). The impact of interactive whiteboards on classroom interaction and learning in primary schools in the UK. In M. Thomas \& E. Schmid (Eds), Interactive whiteboards for education: Theory, research and practice. Hershey, PA: IGI Global, pp. 86-101.

Higgins, S., Falzon, C., Hall, I., Moseley, D., Smith, F., Smith, H. \& Wall, K. (2005). Embedding ICT in the literacy and numeracy strategies: Final report. University of Newcastle Upon Tyne, Newcastle. http:/ / dro.dur.ac.uk/1899/

Hinger, D. (2007). Promising practices in videoconferencing. In G. Richards (Ed.), Proceedings of world conference on e-learning in corporate, government, healthcare, and higher education, p. 2035. Chesapeake, VA: AACE. http:/ / www.editlib.org/p/26655

Kay, R. \& Knaack, L. (2005). Developing learning objects for secondary school students: A multicomponent model. Interdisciplinary Journal of Knowledge and Learning Objects, 1. http: / / ijklo.org/Volume1/v1p229-254Kay_Knaack.pdf

Kitchen, S., MacKenzie, H., Butts, S. \& Finch, S. (2006). Evaluation of curriculum online: Report of the third survey of schools. [viewed 23 Feb 2011] http: / / webarchive.nationalarchives. gov.uk/20101102103654/ publications.becta.org.uk/ / display.cfm?resID=25949

Lee, M. (2010). Interactive whiteboards and schooling: The context. Technology, Pedagogy and Education, 19(2), 133-141. http: / / dx.doi.org/10.1080/1475939X.2010.491215

Lee, M. \& Winzenried, A. (2009). The use of instructional technology in schools. Melbourne: ACER Press.

Jewitt, C., Moss, G. \& Cardini, A. (2007). Pace, interactivity and multimodality in teachers' design of texts for interactive whiteboards in the secondary school classroom. Learning, Media and Technology, 32(3), 303-317. http:/ / dx.doi.org/10.1080/17439880701511149 
Maher, D. (2011). Using the multimodal affordances of the interactive whiteboard to support students' understanding of texts. Learning, Media and Technology, 36(3), 235-250. http: / / dx.doi.org/10.1080/17439884.2010.536553

Mercer, N., Hennessy, S. \& Warwick, P. (2010). Using interactive whiteboards to orchestrate classroom dialogue. Technology, Pedagogy and Education, 19(2), 195-209. http: / / dx.doi.org/10.1080/1475939X.2010.491230

McCormick, D. (2007). Interactive whiteboards in the classroom: A primary teacher's perspective. First International Workshop on Pen-Based Learning Technologies (PLT 2007), pp1-4. http:/ / dx.doi.org/10.1109/PLT.2007.12

Mitchell, J., Hunter, J. \& Mockler, N. (2010). Connecting classrooms in rural communities through interactive whiteboards. In M. Thomas \& A. Jones (Eds), Interactive whiteboards: An Australasian perspective. Australasian Journal of Educational Technology, 26(Special issue, 4), 464-476. http: / / www.ascilite.org.au/ajet/ajet26/mitchell.html

Mumtaz, S. (2000). Factors affecting teachers' use of information and communications technology: A review of the literature. Journal of Information Technology for Teacher Education, 9(3), 319-342. http: / / dx.doi.org/10.1080/14759390000200096

Murcia, K. \& Sheffield, R. (2010). Talking about science in interactive whiteboard classrooms. In M. Thomas \& A. Jones (Eds), Interactive whiteboards: An Australasian perspective. Australasian Journal of Educational Technology, 26(Special issue, 4), 417-431. http: / / www.ascilite.org.au/ajet/ajet26/murcia.html

Reimann, P., Freebody, P., Hornibrook, M. \& Howard, S. (2009). Immersive learning environments: A study of teachers' innovation using The Le@rning Federation's digital learning resources. http:/ / www.ndlrn.edu.au/verve/_resources/Study_of_teachers_using_TLF_resources_2009.pdf

Saw, K. G., Majid, O., Abdul Ghani, N., Atan, H., Idrus, R. M., Rahman, Z. A. \& Tan. K. (2008). The videoconferencing learning environment: Technology, interaction and learning intersect. British Journal of Educational Technology, 39(3), 475-485. http: / / dx.doi.org/10.1111/j.14678535.2007.00736.x

Schmid, E. C. (2010). Developing competencies for using the interactive whiteboard to implement communicative language teaching in the English as a foreign language classroom. Technology, Pedagogy and Education, 19(2), 159-172. http: / / dx.doi.org/10.1080/1475939X.2010.491218

Schuck, S. \& Kearney, M. (2007). Exploring pedagogy with interactive whiteboards. A research report. [viewed 23 June 2009] http:/ / www.eddev.uts.edu.au/teachered/research/iwbproject/pdfs/iwbreportweb.pdf

Strauss, A. \& Corbin, J. (1994). Grounded theory methodology: An overview. In N. K. Denzin \& Y. S. Lincoln (Eds.), Handbook of qualitative research (pp. 273-285). Thousand Oaks, CA: Sage.

Torff, B. \& Tirotta, R. (2010). Interactive whiteboards produce small gains in elementary students' self-reported motivation in mathematics. Computers $\mathcal{E}$ Education, 54(2), 379-383. http: / / dx.doi.org/10.1016/j.compedu.2009.08.019

Underwood, J. (2010). Understanding the impact of technology: Learner and school level factors, 2010. [verified 11 Jan 2012] http:/ / dera.ioe.ac.uk/1434/

Wall, K., Higgins, S. \& Smith, H. (2005). 'The visual helps me understand the complicated things': Pupil views of teaching and learning with interactive whiteboards. British Journal of Educational Technology, 36(5), 851-867. http:// dx.doi.org/10.1111/j.1467-8535.2005.00508.x

Wood, R. \& Ashfield, J. (2008). The use of the interactive whiteboard for creative teaching and learning in literacy and mathematics: a case study. British Journal of Educational Technology, 39(1), 84-96. http:/ / dx.doi.org/10.1111/j.1467-8535.2007.00699.x 


\section{Appendix 1: Survey questions}

- Name of School

- Gender

- How many years have you spent teaching in a primary classroom?

- Please describe the nature of your teaching appointment (drop down list)

- On average, how many hours do you spend teaching in the classroom each week? (excluding administrative responsibilities and release time)

- What grade or year level do you currently teach? (If teaching multiple grades, please select more than one).

- What is the nature of your access to an interactive whiteboard (IWB)? Please click the most appropriate. Please give an estimate of the percentage of your teaching time each week you spend using the IWB directly to support students' learning?

- How would you describe your level of confidence in using the IWB? (out of 10)

- What percentage of your teaching time spent using the IWB is focused on each curriculum area? (for example, you might estimate $30 \%$ of your IWB teaching time is spent on Mathematics, $40 \%$ on English/literacy and $30 \%$ on science). The sum of your answers should total $100 \%$.

- IWB's are generally supplied with specific software design for teachers. There are various brands such as SMART Notebook, ActiveStudio / ActiveInspire, Easiteach. Each have similar features used by teachers to either prepare lessons OR b) deliver lessons in the class with their students. How often do you use the following features of your IWB software? (responses to a list of features in relation to both preparing lessons and use in the classroom)

- Do you use any of the following in conjunction with your IWB? (respond either Never, Sometimes or Frequently to a list of items)

- Many IWB companies produce ready-made lessons for teachers which can be downloaded off the Internet (e.g. from Promethean Planet, SMART Exchange). How often do you do the following? (respond Never, Occasionally or Frequently to a list of items)

- Of course, a whole range of other software can be used on your IWB. How often you use the following in the classroom on your IWB and (if you do) what the main curriculum area is that you would use these for teaching? (respond Never, Occasionally or Frequently to a list of items and indicate main curriculum area)

- Many teachers also make use of online (web-based) resources via their IWB. How often do you use these in the classroom and (if you do) what is the main curriculum area that you would use these for teaching? (respond Never, Occasionally or Frequently to a list of items and indicate main curriculum area)

- There is also a range of other digital resources which some teachers can access for use on their IWBs. For each of the following, please indicate how often you use these in the classroom using your IWB and (if you do) what the main curriculum area is that you would use these for teaching? (respond Never, Occasionally or Frequently to a list of items and indicate main curriculum area)

- What would you see as the most influential factor affecting your choice about what digital resources you use in your teaching?

- How influential are the following factors in terms of your awareness of what digital resources might be available for you to use on your IWB? (respond Not at all influential, Somewhat influential, Very influential to a list of items)

- How influential are the following factors in terms of your decision to use digital resource/s on your IWB? (respond Not at all influential, Somewhat influential, Very influential to a list of items)

- Finally, in relation to your own learning, how helpful are each of the following... (respond not at all, Not really, Maybe, Yes, a little, Yes a lot to a list of items)

- Do you have any further comments you would like to make about this survey or about the resources you use on your IWB? 


\section{Appendix 2: Focus group questions}

Teachers will be asked to introduce themselves and say:

- how long they have been using their IWB

- the thing they like best about their IWB

- and the thing that they like least

Group members will be asked to describe 1-2 resources that they commonly choose to use on their IWB and then provide details on why they choose them and the pedagogical benefits (or disadvantages/challenges) of the resources.

Other teachers will be prompted to respond - to add, agree, disagree etc. [the facilitator/ interviewer will stimulate a discussion about whether these same factors influence others in the group]

To what extent, and in which circumstances, do teachers still choose to use Office applications?

What would be teachers' main words of advice to other teachers using IWBs about choice of digital resources for use in their teaching?

Authors: Dr Damian Maher lectures in Education at the Faculty of Arts and Social Sciences at the University of Technology, Sydney (UTS). The focus of his research is on the use of ICT in primary schools. Email: Damian.Maher@uts.edu.au

Dr Renata Phelps is a Senior Research Fellow with the Centre for Children and Young People at Southern Cross University. She has a keen interest in the role of ICT in supporting innovative pedagogy in schools and she has been involved in developing a metacognitive approach to ICT professional development for teachers known as Technology Together (currently in publication with ISTE).

Email: renata.phelps@scu.edu.au

Ms Nikkita Urane completed her Bachelor of Education (Primary) program at Southern Cross University in 2010 and was involved in the project as part of final year studies. Email: n.urane.10@scu.edu.au

Mr Mal Lee is an educational consultant specialising in the evolution of schooling and technology. He has authored a number of books, including The interactive whiteboard revolution: The teacher's guide to IWBs (Betcher \& Lee, 2009), and Developing a networked school community: A guide to realizing the vision (Lee \& Finger, 2010); both published by ACER Press. Email: mallee@mac.com

Please cite as: Maher, D., Phelps, R., Urane, N. \& Lee, M. (2012). Primary school teachers' use of digital resources with interactive whiteboards: The Australian context. Australasian Journal of Educational Technology, 28(1), 138-158.

http: / / www.ascilite.org.au/ajet/ajet28/maher.html 